\title{
The Application of Corporate Social Responsibility in European Agriculture
}

Abstract

The aim of this article is to show that Corporate Social Responsibility (CSR) can be applied in agriculture as a sustainable development tool. This paper shows the connections between CSR and the Common Agricultural Policy; opinions on socially responsible agriculture expressed by EU citizens are mentioned, and the application of the concept of Corporate Social Responsibility in agriculture is described.

Both CSR and the Common Agricultural Policy are included in the Europe 2020 Strategy. Farmers should take the CSR concept into account when running their farms, a practice that would be welcomed by European citizens. Applying Corporate Social Responsibility in agriculture would contribute to improving the image of farmers as perceived by stakeholders, as well as bringing notable economic, social and environmental benefits. This article is based on the available literature and the results of European public opinion surveys.

\section{Keywords}

Corporate Social Responsibility • agriculture $\bullet$ Common Agricultural Policy

- sustainable development • stakeholders

(C) University of Warsaw - Faculty of Geography and Regional Studies
Ewa Mazur-Wierzbicka

Department of Human Resource Management

Faculty of Economics and Management

University of Szczecin

e-mail: ewa.mazur-wierzbicka@wp.pl

Received: 29 July 2014

Accepted: 10 February 2015

\section{Introduction}

Recently, consumer criticism of agricultural activity and agribusiness has been increasing due to growing ecological awareness, echoing an increasing understanding of how agriculture activity is irresponsible from the social and ecological perspectives (Korzeniowski 2013; Pawlak 2013). Few priorities are of more importance to the European citizens than the security and stability of food supplies, produced in such a manner to guarantee sustainable use of the land and environmental protection. Hence, agriculture has become the subject of open public debate (Jansen \& Vellema 2004). The most heated debate has occurred over the negative externality of food production, the welfare of animals, concerns about using genetically modified organisms (GMOs) and residue levels of pesticides (Jansen \& Vellema 2004; Heyder \& Theuvsen 2008). Therefore, the concept of sustainable development, and its principles and tools implemented in the agriculture activity, has become enormously important.

The future Common Agricultural Policy, facing many new economic, social and environmental challenges, proves that agriculture is heading towards sustainable development. The concept of Corporate Social Responsibility (CSR) could play a crucial role in meeting these challenges.

The aim of this article is to show that Corporate Social Responsibility (CSR) can be applied in agriculture as a sustainable development tool. In order to achieve the article's aims, the following research tasks have been performed: showing the place of CSR in the Common Agricultural Policy, the analysis of EU citizens' expectations as stakeholders in agriculture, and determining the possible application of social responsibility in agriculture. This article is based on the available literature and the results of European public opinion surveys.

The place of CSR in the Common Agricultural Policy

Changing conditions in the agriculture market generate different regulation needs for its participants. Efficient implementation of the agricultural policy assumes the tailoring of applied tools to these needs. The new challenges of the agricultural policy necessitated the implementation of certain reforms to the CAP, which came into force after 2013 (Fig. 1); most of them were determined after the 2008 Health Check.

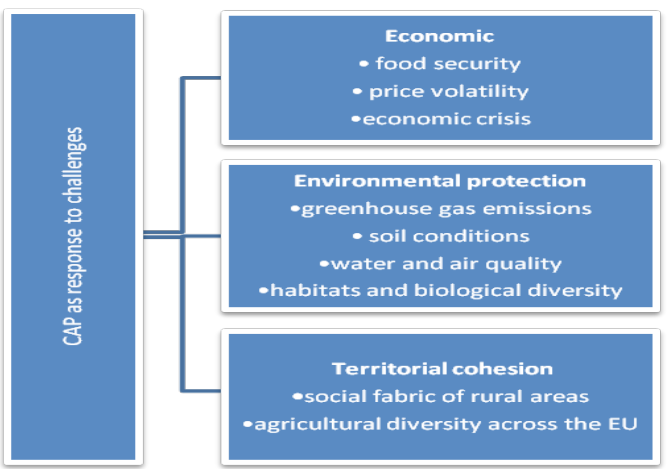

Figure 1. CAP challenge

Source: own compilation 
The stated challenges can be assigned to three groups of factors, which in many cases are external to agriculture. These groups have been identified as economic (including food security and globalisation, declining rate of productivity growth, price volatility, pressures on production costs due to high input prices and deteriorating position of farmers in the food supply chain), environmental (relating to resource efficiency, soil and water quality and threats to habitats and biodiversity), and territorial (where rural areas face demographic, economic and social development, including depopulation and relocation of businesses).

The future CAP will contribute to the implementation of the Europe 2020 Strategy, particularly in terms of:

a) smart growth achieved through innovation in agriculture and the application of modern technologies, generating renewable energy and climate-friendly fertilizing techniques, which should result in the improved transfer of R\&D knowledge to the agricultural food sector, and forestry, with special attention paid to innovation and technologies related to sustainable agriculture and the development of digital society in rural areas,

b) sustainable development based on reasonable land management, producing public goods and reducing $\mathrm{CO}_{2}$ emissions with the aim of improving the competitiveness of the agricultural food sector and forestry, increasing the quality and security of food products, counteracting climate change (Kissinger 2012), and improving natural resource management (biodiversity, water resources and soil protection),

c) inclusive growth, through providing aid to farmers operating in compliance with good agricultural and environmental practices, creating new jobs and developing local markets (The CAP towards 2020, 2010), which should result in diversification and increased viability of rural areas, preventing social exclusion and promoting collaboration among local communities.

The Europe 2020 Strategy (Europe 2020, 2010) also highlights the fact that the CSR role in social and economic reality should be more significant. Corporate Social Responsibility is perceived as one of the tools in sustainable development (indeed, including the term "sustainable" in both concepts refers to the economic, social and ecological aspects) (cf. Porter \& Kramer 2006). It provides the values which contribute to a more cohesive society, and the transition to a sustainable economic system is based on those values. CSR means socially reliable business operated in a transparent manner, taking into account ethical rules, provisions of law, and being responsible for the society, client, natural environment, employee and investor.

The literature is ambiguous in the definition of Corporate Social Responsibility. For this reason, the author of this article uses the CSR definition formulated by the European Commission. CSR is defined by the European Commission as "the responsibility of enterprises for their impacts on society" (Communication from the Commission to the European Parliament 2011). In business operations, CSR focuses on a number of areas, such as market surroundings, public surroundings, employment, environmental protection and relations with investors (Bartkowiak, 2001). Stakeholders play a key role in the CSR concept. According to the author of the stakeholder theory, a stakeholder is "any group or individual who is affected by or can affect the achievement of an organization's objectives" (Freeman 1984). The literature uses 'socially responsible agriculture' and 'sustainable agriculture' interchangeably. Adapted from Beltratti's (2005) interpretation of CSR, this means that "socially responsible farmers do try to maximize their profits but at the same time try to improve the welfare of other stakeholders (citizens)".
The Committee on Twenty-First Century Systems Agriculture (2010) defines sustainable agriculture as progress with respect to four goals:

1. Producing enough to satisfy human needs,

2. Enhancing environmental quality and protecting the natural resource base,

3. Being profitable,

4. Increasing the quality of life for farmers, farm workers, and society as a whole.

If we want to build sustainable agriculture that is socially responsible, we should focus on the core entities in the Common Agricultural Policy. This means that farms have to meet the requirements of their stakeholders, i.e. consumers, the natural environment, and public institutions, as well as make decisions in compliance with the CSR standards. This is so important because consumers, i.e. major stakeholders, have to some extent lost their trust in agriculture as a food provider. This lost trust may be restored by taking the CSR path and implementing the quality and environment management systems and certification systems (there are more than 100 schemes detailing standards related to sustainable agriculture) (Genier, Stamp \& Pfitzer) as well as by acting in a transparent manner (taking pro-society and pro-environmental action) (Jahn, Spiller \& Schramm 2004; Frentrup \& Theuvsen 2006).

The literature also includes publications and research on the prestige of agriculture, improving its image, foodstuffs (Scheper 1999) and food (Langosch \& Schlenz 1990). These topics are of considerable significance, as they often become a point of departure for implementing the CSR standards in agriculture (Zollitsch et al. 2007).

Therefore, the CSR concept should certainly be taken into account in the activities of agricultural entities. In the context of Corporate Social Responsibility, the new CAP objectives should be as follows:

- ensuring a stable framework for the development of agricultural production through an increase in productivity and competitiveness, as well as proper market operation in order to provide consumers with reliable, stable and secure food supplies,

- $\quad$ maintaining the considerable diversity of high quality food products in rural areas and ensuring consumers are wellinformed about the food products they buy,

- ensuring that production adheres to rules of environmental protection (air, soil, water), the welfare of animals, biodiversity and establishing attractive rural areas,

- optimizing the share of EU agriculture in economic opportunities and job creation in rural areas throughout the European Union,

- encouraging management of the land that contributes to the protection of biodiversity, natural resources and habitats, taking regional conditions into consideration,

- providing farmers with fair standards of living and long-term development perspectives, which will attract young men and women to become professional farmers.

Socially responsible agriculture in the opinion of European citizens

Agriculture is crucial to the European Union economy. Therefore, it is necessary to bring about considerable changes and set new directions in the agricultural policy in compliance with the Europe 2020 Strategy and Future Common Agricultural Policy. One of the major issues to be considered is the development of sustainable agriculture which is socially responsible. The importance of this issue is reflected in the attitude of European citizens towards such agriculture. 
More than half of EU citizens are in favour of the high subsidies for farmers allocated in the CAP. Hence, according to data collected by Eurobarometer (Eurobarometer, 2010), the European public expects that the CAP and agriculture will mainly: - $\quad$ ensure agricultural products that are of good quality, healthy and safe (59\% of respondents),

- $\quad$ ensure reasonable food prices (49\%),

- $\quad$ ensure a fair standard of living for farmers (41\%),

- $\quad$ protect the environment $(41 \%)$,

- $\quad$ implement the development of rural areas while preserving the countryside (32\%),

- $\quad$ secure the food supply across the EU (25\%).

The above expectations are in line with the results of the public debate on the future of the CAP after 2013 (more in: The Common Agricultural Policy after 2013, 2010).

The results provided by Eurobarometer show that the overwhelming majority of respondents are supportive of the new objectives proposed in the future CAP, which include (Eurobarometer, 2010):

- $\quad$ preserving the countryside (93\% of respondents),

- helping farmers to face the consequences of climate change $(89 \%)$,

- developing the economy of rural areas (89\%),

- distributing support to farmers in a more equitable way (88\%),

- linking the financial support farmers receive with the compliance to certain rules regarding environmental protection $(87 \%)$,

- $\quad$ encouraging farmers to produce what the markets demand (85\%).

The analysis of the Eurobarometer data confirms that one of the most significant expectations about the CAP is that of safe and healthy food, which means that food security, playing a vital role in the European Union's treaty objectives of the 1957 CAP, has been replaced by the treaty objective of food safety (Wilkin 2009). Meanwhile, another crucial treaty objective of the CAP namely, securing the availability of agricultural supplies - was ranked last in the opinion of European consumers (important to $25 \%$ of respondents). In common with 1957, there are two top priorities still mentioned by EU citizens: ensuring reasonable food prices for consumers (49\%) and ensuring a fair standard of living for farmers $(41 \%)$. In this case, the quality of food supplies matters, meaning the manner in which they are produced and the methods used for production, but not the amount of supplied food. Moreover, some $92 \%$ of respondents from the 28 Member States decided that agriculture and rural areas is an important subject for the future (Eurobarometer 410, 2014).

EU citizens decided that the main reasons for allocating such a large portion of the EU budget to the CAP are as follows (Eurobarometer 410, 2014):

- financial aid to farmers makes it possible to guarantee the food supply to Europeans (44\%),

- financial aid to farmers makes it possible to ensure the production of food products while protecting the environment $(38 \%)$,

- $\quad$ agriculture requires heavy human and financial investments $(28 \%)$,

- the production of food products in the EU is more expensive than in other countries (24\%).

The citizens of the 28 Member States also indicated the responsibilities of farmers in society. They were as follows: supplying the population with a diversity of quality products (cited by $38 \%$ of respondents), maintaining economic activity and employment in rural areas (36\%), protecting the environment $(32 \%)$, ensuring the EU's food self-sufficiency $(29 \%)$, ensuring the welfare of farmed animals ( $27 \%)$, and favouring and improving life in the countryside (21\%) (Eurobarometer 410, 2014).

\section{Corporate Social Responsibility in agriculture}

When analysing the requirements dictated by European society, it is quite obvious that socially responsible farmers should pay special attention to high standards for agricultural production, sustainable agricultural production which is environmentally friendly, the welfare of farmed animals, food security as well as job creation, and the continuous development of employees. Operating farms in this manner requires sufficient investment and security. Thus, the Common Agricultural Policy plays an important role in supporting the operation of such farms, as the economic aspect of CSR. The important issue is the acceptance of the CAP budget by the vast majority of European citizens, to ensure a sufficient standard of living for people employed in agriculture, and that the operation of farms themselves are in line with the CSR economic aspects.

Moreover, citizens (society) play various roles in the agricultural sector in the CSR context. They are both consumers and stakeholders, who are simultaneously facing the externality of agricultural activity. Additionally, they are taxpayers who decide more or less directly on the amount of public aid provided to the agricultural business sector (cf. Caron et al. 2008). As taxpayers, their role is similar to the one played by stakeholders - that of shareholders.

By 'investing' (taxes) into 'enterprise' (the agricultural food sector), citizens are entitled to decide on 'the enterprise objectives' and, as a result, they expect some benefits from the multifunctionality of agriculture. These may result from commercial functions performed by the agricultural food sector (e.g. production of food, fuel and energy, providing tourist services) as well as non-commercial functions (provision of public goods) (Wilkin 2010). As far as investors (taxpayers) are concerned, multifunctional agriculture will be expected to produce some intangible added value in the form of nonproduction goods.

At this point a further issue should be raised, regarding whether entrepreneurs should bear the cost of their socially responsible action on their own or be paid for it from taxpayers' money, as is currently the case. Based on a number of economic assumptions, it seems that applying interventionism in this case is justified (Duer 2010). Additionally, it should be taken into account that due to entrepreneurs' anonymity, it is difficult for them to establish an appropriate position or good reputation among the final recipients (Jensen 2001). This fact certainly does not encourage entrepreneurs to implement the agricultural CSR standards. A farmer, other than being a socially responsible 'entrepreneur' supplying produced goods as semi-finished products to other entities, becomes a stakeholder, i.e. a supplier who is socially responsible for acting in compliance with the CSR standards for food processing or distribution. It is observed in economic practice that socially responsible producers selling their final goods in the market require ecological and social responsibility from their cooperators and suppliers. It should also be noted that, due to the activities farmers conduct, they have a weaker bargaining power compared to large suppliers, food processors and retailers. Therefore, the added value produced by farmers is less wellcompensated than the added value produced by the other links in the agricultural food chain. Hence, socially and economically responsible farms contribute significantly to orienting agriculture towards sustainable development. As a consequence, rural areas serve a number of functions, particularly (Baum 2003; Puślecki, Kmieciak \& Walkowski 2010; Caron et al. 2008): 
- the production of food of a particular quality and amount,

- $\quad$ ensuring sufficient standards of living for rural inhabitants (technical infrastructure, providing work and fair income),

- environmental protection (protection of soil, water, air, maintaining ecosystem stability and biodiversity),

- maintaining and developing the aesthetic and recreational values of rural areas (the role of the countryside),

- $\quad$ ensuring health and welfare of people and animals.

Therefore, applying the CSR concept in agriculture is justified. Hence, it is crucial for entities from the agricultural food sector and agricultural business to promote the CSR concept and to introduce incentives for implementing its standards in accordance with the CAP. This action would be in line with the general EU orientation set up by the Europe 2020 strategy.

\section{Conclusions}

The reasoning provided in this article has allowed the article objective to be met and additional conclusions can be drawn, namely:

The 2014-2020 CAP should be integrated into a transformation of the EU economy towards a sustainable economy pursuant to the assumptions of the Europe 2020 Strategy. This means that the CAP should be better adapted to economic, environmental and territorial challenges, more sustainable, and better oriented to simplified and effective instruments.

To achieve such a goal, the following objectives of the future CAP should be met (The CAP towards 2020, 2010, pp. 7-8):

Objective 1: viable food production (sufficient, steady incomes; to improve the competitiveness of the agricultural sector and to enhance its value share in the food chain; to compensate for production difficulties in areas with specific natural constraints),

Objective 2: sustainable management of natural resources and climate action (environmental public goods; green growth through innovation; climate change mitigation and adaptation),

Objective 3: balanced territorial development (to support rural employment and maintain the social fabric of rural areas; diversification; to allow for social and structural diversity of rural areas).

To a large extent, the proposed CAP reform orientations reflect social expectations resulting from a growing awareness of ecological and economic threats. The Common Agriculture Policy should be 'equipped' in instruments to ensure both food security and environmental protection and the creation of new jobs. Farmers should be encouraged effectively in order to meet the stated challenges - this could be achieved by greater participation from the various entities of the agricultural food chain, urging them to implement the CSR standards. The CSR concept would supplement existing concepts of developing agriculture in the European Union, due to the fact that key aspects of Corporate Social Responsibility are common to the models of multifunctional and sustainable development.

Conducting business in agriculture in compliance with the Corporate Social Responsibility standards, considered as a tool in sustainable development, could bring a number of the benefits expected by European citizens (and not only by them). These are as follows: food security for European consumers via the preservation of food potential on a sustainable basis throughout the EU, increased market stability for consumers and farmers, sustainable production in line with the standards for food security, traceability, the environment and animal welfare (the stated standards are the most stringent in the world), employment and economic viability in rural areas (at present almost 30 million people are employed on farms and over 40 million people work in the agricultural food chain), and maintaining the production system/ low-return-investments/ high natural value (e.g. natural meadows, forestry).

In conclusion, EU agriculture needs to increase the production of safe and quality food, while preserving the natural resources that agricultural productivity depends upon. This can only be achieved by a competitive and viable agricultural sector operating within a properly functioning supply chain, which also contributes to the maintenance of a thriving rural economy. In addition, to achieve these long-term goals, more efficient allocation of the available CAP budget will be required.

\section{References}

Bartkowiak, G 2001, Społeczna odpowiedzialność biznesu w aspekcie teoretycznym i empirycznym, Difin, Warszawa.

Baum, R 2003, 'Kryteria oceny zrównoważonego rozwoju w gospodarstwach rolnych' Roczniki Akademii Rolniczej w Poznaniu, no. CCCLVIII, pp. 3-10.

Beltratti, A 2005, 'The complementarity between corporate governance and corporate social responsibility', The Geneva Papers on Risk and Insurance - Issues and Practice 30(3) pp. 373-386.

Caron, P, Reig, E., Roep, D, Hediger, W, Le Cotty, T, Barthélemy, D, Hadynska, A, Hadynski, J, Oostindie, H \& Sabourin, E 2008, 'Multifunctionality: refocusing a spreading, loose and fashionable concept for looking at sustainability?' International Journal of Agricultural Resources, Governance and Ecology 7 (4-5), pp. 301-318.

Committee on Twenty-First Century Systems Agriculture; National Research Council 2010. Toward Sustainable Agricultural Systems in the 21st Century, National Academy of Sciences. Available from: <http://www.nap.edu/catalog/12832.html>

Communication from The Commission to the European Parliament, The Council, The European Economic and Social Committee and the Committee of the Regions, A renewed EU strategy 2011-14 for Corporate Social Responsibility, Brussels, 25.10.2011 COM(2011) 681.
Duer, I 2010, 'Dobra publiczne użytkowane i dostarczane przez rolnictwo - wspierane w ramach programu rozwoju obszarów wiejskich, in Możliwości rozwoju obszarów problemowych rolnictwa (OPR) w świetle PROW 20072013', Studia i raporty IUNG-PIB, Puławy, nr 21, ss. 85-86.

Eurobarometer 336, Europeans, Agriculture and the Common Agricultural Policy, European Commission. March 2010.

Eurobarometer 410, Europeans, Agriculture and the Common Agricultural Policy (Cap), European Commission. March 2014.

Europe 2020. A strategy for smart, sustainable and inclusive growth, Communication from the Commission, Brussels, 3.3.2010, $\operatorname{COM}(2010) 2020$ final.

Freeman, R, E 1984, Strategic Management: a Stakeholder Approach, Pitman, Boston.

Frentrup, M \& Theuvsen, L 2006, 'Transparency in supply chains: Is trust a limiting factor?' in Trust and risk in business networks, eds M Fritz, U Rickert \& G Schiefer, Bonn.

Genier, C, Stamp, M \& Pfitzer, M n.d., Corporate social responsibility in the agrifood sector: harnessing innovation for sustainable development. Available from: <http://www.fsg.org/tabid/191/Articleld/296/Default. aspx?srpush=true>. [10 February 2014]

Heyder, M \& Theuvsen, L 2008, 'Legitimating business activities using Corporate Social Responsibility: Is there a need for 
CSR in agribusiness?' in System dynamics and innovation in food networks 2008, eds M Fritz, U Rickert U \& G Schiefer, ILB-Press, Bonn

Jahn, G, Spiller, A \& Schramm, M 2004, Trust in certification procedures: An institutional economics approach investigating the quality of audits within food chains, Paper presented at 14th IAMA Conference, June 12-15, 2004, Montreux, Switzerland.

Jansen, K \& Vellema, S (eds.) 2004, Agribusiness and society: Corporate responses to environmentalism, market opportunities and public regulation, Sage, London.

Jensen, M 2001, Value maximization, Stakeholder Theory and the corporate objective function, Journal of Applied Corporate Finance no. 14 (3).

Kissinger, G 2012, 'Corporate social responsibility and supply agreements in the agricultural sector Decreasing land and climate pressures', CCAFS Working Paper no. 14. CGIAR Research Program on Climate Change, Agriculture and Food Security (CCAFS), Copenhagen, Denmark.

Korzeniowski, S 2013, Rolnictwo energetyczne i precyzyjne wybrane zagadnienia, Wyd. PWSZ Suwałki.

Langosch, R \& Schlenz, U 1990, 'Image und public relations im agrarsektor', Berichte über Landwirtschaft, 68, pp. 19-31.

Pawlak, K 2013, Międzynarodowa zdolność konkurencyjna sektora rolno-spożywczego krajów Unii Europejskiej, Uniwersytet Przyrodniczy w Poznaniu, Poznań.
Porter, ME \& Kramer, MR 2006, 'Strategy \& society. The link between competitive advantage and corporate social responsibility', Harvard Business Review, vol. 84 (12), p. 78-92.

Puślecki, ZW, Kmieciak, R \& Walkowski, M 2010, Wspólna Polityka Rolna w warunkach wzrostu konkurencyjności Unii Europejskiej, Dom Wydawniczy ELIPSA, Warszawa.

Scheper, U 1999, Das image der landwirtschaft bei meinungsmultiplikatoren, Shaker, Aachen.

The CAP towards 2020: Meeting the food, natural resources and territorial challenges of the future, Communication from the Commission, Brussels, 18 November 2010 COM(2010) 672 final

The Common agricultural policy after 2013. Public debate, European Commission, lipiec 2010.

Wilkin, J (ed.) 2010, Wielofunkcyjność rolnictwa. Kierunki badań, podstawy metodologiczne i implikacje praktyczne, Instytut Rozwoju Wsi i Rolnictwa Polskiej Akademii Nauk, Warszawa.

Wilkin, J 2009, 'Wielofunkcyjność rolnictwa - konceptualizacja i operacjonalizacja zjawiska', Wieś i Rolnictwo, no. 4, pp. 9-28.

Zollitsch, W, Winkler, C, Waiblinger, S \& Haslberger, A 2007, Sustainable food production and ethics, Wageningen Academic Publishers, Wageningen. 